\title{
MULTICULTURAL APPROACH BASED EDUCATION MODEL CONTRIBUTION TOWARDS APPRECIATION OF THE VALUES OF LOCAL WISDOM OF ELEMENTARY SCHOOL STUDENTS IN BANDAR LAMPUNG INDONESIA
}

\author{
Sudjarwo Sudjarwo ${ }^{1}$, Sunyono Sunyono ${ }^{2}$, Herpratiwi Herpratiwi ${ }^{3}$ \\ ${ }^{1}$ Professor of the Graduate Program, Faculty of Teacher Training and Education, University of Lampung, \\ Indonesia, e-mail: profdrsudjarwo@gmail.com \\ ${ }^{2}$ Chemistry Education Study Program, Faculty of Teacher Training and Education, University of Lampung, \\ Indonesia, e-mail: sunyono.1965@fkip.unila.ac.id. Corresponding Author. \\ ${ }^{3}$ Education Technology Study Program, Faculty of Teacher Training and Education, University of Lampung, \\ Indonesia, e-mail: herpratiwi64@yahoo.com.
}

\begin{abstract}
The personality of the learner is determined by the strength and ability of the local genius, so as to enable development in the future. Schools, especially basic education should make a habit of multi-cultural approach to integrate the values of local cultural wisdom in the process of learning in the classroom, extra curricular or student activities. The aim of the research was to examine the contribution of educational model based on the multi-cultural approach to appreciating the value of local wisdom. The research used a quasi experimental, the study population is elementary school students, the sampling is determined by use an error rate of $5 \%$, so that the number of samples is 40 students of the sixth grade. The research was conducted for one semester. The data of local wisdom value appreciation was collected through a questionnaire consisting of 5 aspects, namely: local knowledge, local culture, local skills, local resources and local social process and was analyzed descriptivequantitatively and statistic by $t$ test. The result of the research is that the application of an education model based on multicultural approach contributed to the appreciation of the value of local wisdom
\end{abstract}

Keywords: basic education model, multi-cultural approach, local wisdom

\section{INTRODUCTION}

Appreciation of the value of local wisdom is the ability, attitude and behavior of a person in using his or her mind to respond to events, objects or situations of values and norms prevailing in a society of noble values which are believed to be true and becomes a reference for daily action and behavior. Appreciation of the value of local wisdom becomes something that is very important for students in the midst of globalization and the development of limitless science and technology. Local wisdom is an entity that greatly determines the degree and dignity of man in the community and its truth that has become a tradition or a constant throughout the existence of such society. (Al Wasilah, 2009; Erwan, 2012; Keraf, 2010; Ridwan, 2007; Sartini, 2004; Sibarani 2012).

The value of local wisdom should be instilled in students especially in the formal education environment as a center of culture of competence, basis for character development, personality, high work skills, work culture and learning culture. Formal education should be oriented towards efforts to preserve the culture due to the influx of globalization and foster positive attitudes toward cultural values, and constructive for the creation of social integration in people's lives, (Musanna, 2011). Education is also expected to equip students to have adaptive skills, and promote the intellectual, moral and socio-cultural aspects (Phinney, 1990). Within the value of local wisdom there is a mechanism of living life as reflected in a particular social order and is based on the aspect of life which consists of five dimensions, namely local knowledge, local culture, local skills, local resources and local social processes (Ife , 2002).

Education can be a means of building a civilization based on the cultural values of the Indonesian nation, to ensure cultural stability and validity (Al Muchtar, 2000). Therefore, it is necessary to reinterpret and revitalize the world of education, so as not to be deprived of the cultural values of the Indonesian nation through an educational program based on a multicultural approach, so that education has the robustness of internal logic, Submit Date: 11.02. 2018, Acceptance Date: 27.02.2018, DOI NO: 10.7456/1080MSE/103

Research Article - This article was checked by Turnitin 
has the power of openness and flexibility in accepting the contribution of thought from external logic. Education that ignores and even abandons local cultural values, will be the cause of the decline of local culture in the lives of generations to come.

Multicultural-based education is an oriented effort to preserve the culture from the consequences of globalization and foster a positive and constructive attitude for the creation of harmonious social integration in people's lives. In addition, the main goal of a multicultural-based approach to education is to equip students to have an adaptive ability that embraces the intellectual, moral and socio-cultural aspects, as well as an effort to realize the hope of the Indonesian nation's future as a nation of dignity and having a personal identity.

Education as the process of intellectual and emotional basic formation of skills to nature and fellow human beings, so that students as successors can appreciate, understand and practice the values or norms by way of inheriting all experiences, knowledge, capabilities and skills that is the background of values and norms of living and life. Education not only serves to conduct transformation, namely the change and renewal of society along with its cultural values, but also functions in inheriting or preserving the cultural values of society and or maintaining the continuity of the existence of society. Values are at the core of a cultural system, and the core culture consists of a series of concepts in general and value systems in particular. This is because there are values, knowledge, and behavior patterns in the community that are still relevant and considered good which must be preserved, (Alwasilah, 2009) through education. Education as a social institution to maintain and preserve local culture so that education will contribute to provide color for the nation in finding its identity.

Education can not be separated from culture (Vygotsky, 1990; Tilaar, 2002). Education based on multicultural approach will identify the strengths of students contextually to do something with their potential to reduce loss of identity, social sensitivity, and social intelligence. The multi-cultural approach-based education will explore the uniqueness of local wisdom along with the cultural values of the nation that exist in all the members of the school and all the components contained in education, so that education is based on an anthropological, sociological and cultural approach. Thus students will recognized and appreciated the local culture and themselves. Education as a cultural center and a center for dialogue and communication among local residents so that they can exchange ideas, cooperate, be mutually respectful and view differences as potentially useful for all parties.

Education-based multicultural approach is a process of internalization of cultural values performed in a planned and programmed manner. This education is oriented on the awareness of the importance of local culture as an identity that must be maintained, preserved and developed and used as a guide in life, (Suastra, 2011, Zuriah, 2011). Internalization of local wisdom values can be done through learning that comes from the values of local wisdom with a learning approach and strategy that emphasizes the contextualization of students' knowledge, so as to have an impact on appreciating the value of local wisdom (Amirin, 2012).

Based on the above, an assessment is conducted that aims to analyze the contribution of education based on a multicultural approach to appreciating the value of local wisdom of elementary school students in Bandar Lampung- Indonesia.

\section{METHODOLOGY OF RESEARCH}

The study used a quasi-experimental, aimed at measuring impacts, and creating comparisons in order to deduce changes induced by treatment and to reveal causal relationships that are non-deterministic but only the probability or increasing the probability of occurrence (Cook \& Campbell, 1979; Shadish, 1995 Shadis et al, 2002).

The sample is determined by the strata random sampling technique, by sampling from a population randomly. The population is upper elementary school students of grade IV, V and VI from 6 schools. Samples are obtained directly from the sampling unit, so each sampling unit gets the same opportunity to become a sample, (Roscoe, 1975). The number of samples is determined with the Isaac and Michael Table (Isaac, 1981) with an error rate of 5\%, so the number of samples is 40 higher elementary school students, namely grade VI. The study was conducted for one semester, once a week.

The data of appreciating the value of local wisdom is collected through a questionnaire instrument consisting of 5 aspects, namely local knowledge, local culture, local skills, local resources and local social process, (Ife, Submit Date: 11.02. 2018, Acceptance Date: 27.02.2018, DOI NO: 10.7456/1080MSE/103

Research Article - This article was checked by Turnitin 
2002) where the statements are self-developed by the authors, namely local knowledge ( 8 statements, item numbers 1 to 8), local culture (7 statements, item numbers 9 through 15), local skills (5 statements, item numbers 16 to 20), local resources (5 statements, item numbers 26-30) and local social processes (5 statements, item numbers 26 to 30 ) as shown in Table 1.

Table 1 Appreciation of the Value of Local Wisdom Questionnaire Instrument Aspect and Number of Statements

\begin{tabular}{ll}
\hline \multicolumn{1}{c}{ Aspek Pengukuran } & No of items \\
\hline Local Knowledge & 8 items \\
Local Culture & 7 items \\
Local Skills & 5 items \\
Local Resources & 5 items \\
Local Social Process & 5 items \\
Total & 30 items \\
\hline
\end{tabular}

Table 2 shows the reliability value of the questionnaire instrument aspect of appreciating the value of local wisdom, where the local knowledge aspect earns Cronbach's Alpha value of 0.85, local culture with Cronbach's Alpha value of 0.83, local skill with Cronbach's Alpha value of 0.89, local resources with a Cronbach's Alpha value of 0.87 , and the local social process with Cronbach's Alpha value of 0.91 . Based on the reliability test, all aspects have Cronbach's Alpha value of 0.967, thus all items contained in the questionnaire are reliable and all tests are internally consistent because they have strong reliability (Maier, Wolf, \& Randler, 2016; Bonett \& Wright, 2015; Rainsch, 2004).

Table 2 Wisdom Value Appreciation Questionnaire Instrument Aspect Reliability Value

\begin{tabular}{cc}
\hline Measuring Aspect & Cronbach's Alpha Value \\
\hline Local Knowledge & 0,85 \\
Local Culture & 0,83 \\
Local Skills & 0,89 \\
Local Resources & 0,87 \\
Local Social Process & 0,91 \\
Total & 0.87 \\
\hline
\end{tabular}

Table 3 shows that all data after being tested with one-sample of the kolmogorov-smirnov test (Yu et al., 2008) is normal. The local knowledge aspect is 0.212 , local culture aspect is 0.228 , local skills aspect is 0.235 , local resource aspect is 0.237 and local social process aspect is 0.223 , all with significance value of 0.20 , this indicates that the sample is normally distributed.

\section{Table 3 Data normality test results}




\begin{tabular}{|lcc}
\hline \multicolumn{1}{c}{ Measuring Aspect } & Komogorov Smirnov & Significance Value \\
\hline Local Knowledge & 0,212 & 0,20 \\
Local Culture & 0,228 & 0,20 \\
Local Skills & 0,235 & 0,20 \\
Local Resources & 0,237 & 0,20 \\
Local Social Process & 0,223 & 0,20 \\
\hline
\end{tabular}

Based on a homogeneity test using oneway Anova (Donald, 2010), the sig. 0.100>0.05 value was known, indicating that the sample is homogeneous. The data was analyzed by paired sample t-test because of using one sample t-test design (Donald, 2010). Step-by-step data analysis is seen in Table 4.

Table 4 Steps of data analysis

\begin{tabular}{cll}
\hline Steps & \multicolumn{1}{c}{ Purpose } & \multicolumn{1}{c}{ Analysis } \\
\hline 1 & Reliability Assesment & Chronbach's Alpha test \\
2 & Reationships among variables & Correlation analysis \\
3 & $\begin{array}{l}\text { Difference test before and after } \\
\text { treatment }\end{array}$ & Paired Sample t-test \\
\hline
\end{tabular}

\section{RESULTS OF THE RESEARCH}

The mean and standard deviation of 5 aspects of appreciating the value of local wisdom has been compared. Table 5 shows that the highest average is the local knowledge aspect $(6,725 \pm 1.109)$, followed by local culture with an average of $(6,575 \pm 0,594)$, local social process aspect with an average of $(4,9 \pm 0,303)$, local resource aspect with an average score of $(4.5 \pm 0,679)$ and local resource aspect with average value $(4,45 \pm 0,679)$. Of the three categories, the lowest is the aspect of local resources and the highest is the knowledge aspect.

Table 5. Mean and standard deviation of character value

\begin{tabular}{lcc}
\hline \multicolumn{1}{c}{ Character Value } & Mean & Std. Deviation \\
\hline Local Knowledge & 6,725 & 1.109 \\
Local Culture & 6,575 & .594 \\
Local Skills & 4,45 & .577 \\
Local Resources & 4,5 & .679 \\
Local Social Process & 4,9 & .303 \\
\hline
\end{tabular}

Differences of Student Pre-Tests and Post-Tests Values on the Appreciation of the Value of Wisdom Table 6 shows the results of descriptive statistical analysis, the pre-test average was $55.22 \pm 4,30$ with an average error standard of 0.867 and post-test average of $76.77 \pm 4.322$ with a standard error of 0.867 . 
Table 6. Paired samples statistics

\begin{tabular}{rcccc}
\hline & Mean & N & $\begin{array}{c}\text { Std } \\
\text { Deviation }\end{array}$ & $\begin{array}{c}\text { Std Error } \\
\text { Mean }\end{array}$ \\
\hline Pair 1 Pre-test & 55,22 & 40 & 4,300 & .867 \\
Post-test & 76,77 & 40 & 4,322 & .867 \\
\hline
\end{tabular}

Table 7 shows the average difference test result between pre-test and post-test values. The test results show that the value of $t$ was -17.590 with a sig of ( 2 tailed) 0,000 . This shows that there is a difference between the pre-test and the post-test value and because the value of $t$ was found to be negative, it indicates that the posttest was better than the pre test. Thus there were differences in appreciation of the value of the wisdom by students before and after being taught with the multicultural approach based education model. After being taught with a model of education based on a multicultural approach, appreciation of the value of local wisdom of higher elementary school students of class VI was higher than the previous level of appreciation.

Table 7. Paired samples test

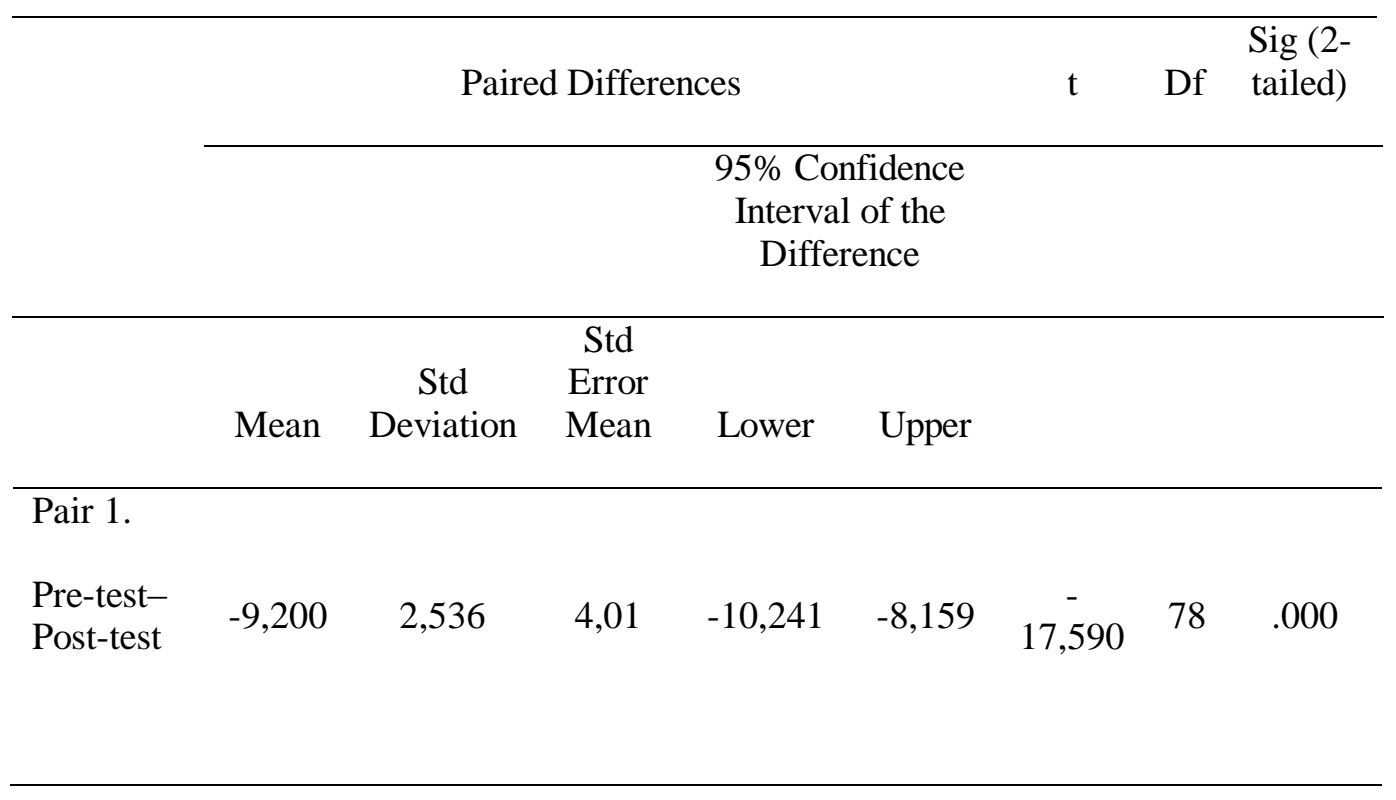

\section{DISCUSSION}

Based on the analysis, it appears that the appreciation of the value of local wisdom of elementary school students was higher after being taught with a model of education based on a multicultural approach than before. Thus the multicultural approach based education model proved to be able to shape the appreciation of the local wisdom of students. The educational model based on multicultural approach was capable of increasing the students' appreciation of local wisdom values because with that model the students were instilled with locality learning, local cultures, local skills, local resources and local social processes (Ife, 2002). With a model of education based on a multicultural approach, the students experienced an internalization process of local wisdom values so that appreciation of such values would emerge.

With an educational model based on a multicultural approach, the value of local wisdom would be able to be taught with a hierarchical syntax and tailored to the character of the student. If a multi-cultural approach-based educational model is used consistently, students will be familiarized to recognize, accept, and respond to local wisdom and ultimately appreciate it well. The multi-cultural approach-based education model provides 
opportunities for students to appreciate the value of local wisdom and develop skills in ways of creating something based on local wisdom, which simutaneously also develops knowledge towards such values.

There are 5 aspects that make up the value of local wisdom, namely local knowledge, local culture, local skills, local resources and local social processes (Ife, 2002). Table 5 shows that the aspect of local knowledge is more dominant in shaping appreciation toward the value of local wisdom, followed by local culture, local social processes, local resources and social skills. This indicates that the knowledge aspect will affect the appreciation of the value of local wisdom. It turns out that the higher or lower levels of knowledge of local values will cause higher-lower appreciation of the value of local wisdom. This study indicates that the appreciation of the value of local wisdom is shaped by the knowledge aspect of the local wisdom values which were conditioned by the teacher through a model of education based on a multicultural approach. The steps of the multi-cultural approach-based educational model will train students to identify as well as being able to internalize such values.

The commitment of teachers to use a model of education based on a multicultural approach in teaching will contribute greatly to the appreciation of the local wisdom values of students. Habits made with syntax that incorporates the values of local wisdom materials will stimulate students to receive and appreciate the value of local wisdom. Instilling local wisdom values using a multi-cultural approach based education model that is not integrated with the school system and culture is unlikely to succeed (Al Hamdani, 2016).

\section{CONCLUSION}

The educational model based on multicultural approach as an intervention to increase the appreciation of the values of local wisdom of students in elementary school. The appreciation of the values of local wisdom is built from aspects of local knowledge, local culture, local skills, local resources and local social processes. Therefore it is necessary to re-design and re-formulate the syntax of education model based on multicultural approach as an important variable in appreciating the values of local wisdom. It is also necessary to develop further research, especially on the questionnaires used to measure the appreciation of the values of local wisdom in order to increase standardization, which contains a more comprehensive aspect.

\section{KNOWLEDGEMENT}

Researchers would like to thank the Institute for Research and Community Service, University of Lampung, which has provided funding this research through Competitive Research Grant scheme Year 2015. Thanks also goes to the head writer and high school chemistry teachers in Lampung Indonesia that has helped smooth the study.

\section{REFERENCES}

Al Hamdani, D. (2016). The Character Education In Islamic Education Viewpoint. Jurnal Pendidikan Islam, 1(1), 98-109.

Al Muchtar, S. (2001). Pendidikan \& Masalah Sosial Budaya (Education \& Socio-Cultural Issues). Bandung: Gelar Pustaka Mandiri Press.

Alwasilah, A. C, et al. (2009). Etnopedagogi: Landasan praktek pendidikan dan pendidikan guru (Etnopedagogi: The cornerstone of teacher education and education practice). Bandung: Kiblat Buku Utama Press.

Amirin, T. M. (2012). Implementasi Pendekatan Pendidikan Multikultur Kontekstual Berbasis Kearifan Lokal di Indonesia (Implementation of Contextual Multicultural Education Based Approach to Local Wisdom in Indonesia). Jurnal Pembangunan Pendidikan: Fondasi dan aplikasi, I(1).

Bonett, D. G., \& Wright, T. A. (2015). Cronbach's alpha reliability: Interval estimation, hypothesis testing, and sample size planning. Journal of Organizational Behavior, 36(1), 3-15.

Cook, DT \& Campbell, DT. (1979). Quasi Experimentation: Design \& Analysis for Field Settings. Houghton Mifflin Company: Boston.

Donald Ary. Lucy Cheser Jacobs, \& Chris Sorensen. (2010). Introduction to Research in Education: Eight Edition. Canada: Nelson Education ltd.

Erwan Baharudin, (2012). Kearifan Lokal, Pengetahuan Lokal dan Degradasi Lingkungan (Local Wisdom, Local Knowledge and Environmental Degradation). Available on: http://www.esaunggul.ac.id/epaper/kearifan-lokal-pengetahuan-lokal-dan-degradasi-lingkungan

Ife, J. (2002). Community Development, Community-Based Alternatives in an. Age Of Globalisations. Australia: Longman Pearson Educations.

Submit Date: 11.02. 2018, Acceptance Date: 27.02.2018, DOI NO: 10.7456/1080MSE/103

Research Article - This article was checked by Turnitin

Copyright $\odot$ The Turkish Online Journal of Design, Art and Communication 
Isaac, S. \& Michael, W. B. (1981). Handbook in Research and Evaluation for Education Sciences (2nd ed.). San Diego 92107: EdITS Publishers.

Keraf, A. S. 2010. Etika Lingkungan Hidup (Environmental Ethics). Jakarta: Penerbit Buku Kompas Press. Maier, U., Wolf, N., \& Randler, C. (2016). Effects of a computer-assisted formative assessment intervention based on multiple-tier diagnostic items and different feedback types. Computers \& Education, 95, 85-98.

Musanna, A. (2011). Rasionalitas dan Aktualitas Kearifan Lokal sebagai Basis Pendidikan Karakter (Rationality and Actuality of Local Wisdom as Character Education Basis). Jurnal Pendidikan dan Kebudayaan, 17(5), 588-598

Phinney Jean S. And Linda Line Alipuria. (1990). Ethnic Identity In College Student From Four Ethnic Groups. Journal of Adolescence, 13, 171-183.

Roscoe, J.T. (1975). Fundamental Research Statistic for The Behavior Sciences. (2nd,ed), Holt. New York: Rinehart and Winston.

Ridwan, Nurma A. (2007). Landasan Keilmuan Kearifan Lokal (Scientific Knowledge Base). Jurnal Studi Islam dan Budaya. Vol. 5, (1), 27-38

Sartini. (2004). Menggali Kearifan Lokal Nusantara Sebuah Kajian Filsafat (Excavating Local Wisdom Nusantara A Study of Philosophy). Jurnal Filsafat, Agustus 2004, Jilid 37, Nomor 2 pp: 111-120.

Rainsch, S. (2004). Dynamic Strategic Analysis: Demistyfying Simple Success Strategies.Wiesbaden: Deutcscher Universitasts-verlag.

Shadish, W. R. (1995). Philosophy of Science an the Quantitatve-Qualitative Debates: Evaluation and Program Planning, 18,1.

Shadish, W. R., Cook, T. D., \& Campbell, D. T. (2002). Experimental and Quasi-Experimental Design for Generalized Causal Inference. Houghton Mifflin Company: Boston.

Sibarani, R. (2012). Kearifan Lokal: Hakikat, Peran, dan Metode Tradisi Lisan (Local Wisdom: The Nature, Roles, and Methods of Oral Tradition). Jakarta: Asosiasi Tradisi Lisan (ATL).

Suastra, I. W., Tika, K., \& Kariasa. (2011). Efektivitas Model Pembelajaran Sains Berbasis Budaya Lokal untuk Mengembangkan Kompetensi dasar Sains Berbasis Budaya Lokal untuk Mengembangkan Kompetensi Dasar Saina dan Nilai Kearifan Lokal di SMP (Effectiveness of Local Culture-Based Science Learning Model to Develop Basic Competence of Local Culture-Based Science to Develop Basic Competence of Saina and Value of Local Wisdom in Junior High School). JPPP Lemlit, 5(3).

Tilaar H.A.R. (2002). Pendidikan, Kebudayaan, dan Masyarakat Madani Indonesia (Education, Culture, and Civil Society of Indonesia). Bandung: Rosdakarya Press.

Vigotsky and Education. (1990). Instructional Implications and Applications of Sociohistirical Psychology. Cambridge: New York.

$Y u$, H., Zheng, Zhao, B, Y., \& Zheng, W. (2008). Understanding User Behavior in Large Scale Video on Demand Systems. In L Song (ed) Collaboration: New York

Zuriah, N. (2011). Model Pengembangan Pendidikan Kewarganegaraan Multikultural Berbasis Kearifan Lokal dalam Fenomena Sosial Pasca Reformasi di Perguruan Tinggi (Multicultural Development Model of Multicultural Education based on Local Wisdom in Post-Reform Social Phenomenon in Higher Education). Jurnal Penelitian Pendidikan. 12(1). 75-86 